\title{
Reflexiones sobre el género del sustantivo sartén en la diacronía del español
}

\author{
Reflections about the noun sartén in Spanish diachrony
}

\author{
Pilar Montero Curiel \\ Universidad de Extremadura \\ pmontero@unex.es
}

ORCID iD: https://orcid.org/0000-0002-1911-0870

RESUMEN: El diccionario de la Real Academia Española toma sartén como un sustantivo femenino y remite al latín SARTAGO, -INIS para justificar la primacía de su género etimológico (femenino) en español. Sin embargo, en determinadas áreas del continente americano el vocablo se emplea también en masculino; representa así una variante diatópica que convive con la femenina y que el propio diccionario académico tiene en cuenta en sus ediciones modernas. A revisar la historia de esta alternancia y a trazar sus áreas actuales de influencia se dedicarán las páginas del presente estudio.

Palabras clave: sartén, género ambiguo, español de América, variación lingüística.

ABSTRACT: The Dictionary of the Royal Spanish Academy takes sartén as a feminine noun and refers to the Latin SARTAGO, -INIS to justify the primacy of its etymological gender (feminine) in Spanish. However, in certain areas of the American continent the word is also used in masculine; it represents a diatopic variant that coexists with the feminine and that the academic dictionary itself takes into account in its modern editions. To revise the history of this alternation and to trace its current areas of influence will be devoted the pages of this study.

Keywords: sartén, ambiguous genre, Spanish of America, linguistic variation.

\section{INTRODUCCIÓN}

Algunos tratados sobre la morfología de la lengua española sugieren que determinados sustantivos son ambiguos en cuanto al género porque se emplean indistintamente con artículo masculino o femenino sin modificar sus significa- 
dos (Alcina y Blecua, 19834: 543-525; Alarcos, 1994: 62; Bosque y Demonte, 1999: 4857). En el caso de sartén, la ambigüedad viene dada por circunstancias geográficas que han motivado históricamente que el español peninsular prefiera el género femenino y que buena parte de los países hispanoamericanos y algunas regiones de España hayan optado bien por el uso del género masculino, bien por el femenino o bien por una alternancia entre ambos para designar el mismo objeto.

La Nueva Gramática de la Lengua Española define los sustantivos ambiguos en cuanto al género como aquellos "que pueden aparecer en masculino o femenino" y designan "en ambos casos la misma entidad, generalmente inanimada, como en el mar/la mar o el tiznella tizne" (NGLE: 83) o, por decirlo con otras palabras, aquellos sustantivos que "poseen los dos géneros pero no designan, por lo general, seres sexuados" (113). La Academia completa la nómina de sustantivos ambiguos en cuanto al género, ilustrada en su primer acercamiento con mar y tizne, con otros como agravante, armazón, azumbre, interrogante, maratón, prez, pringue (para nombrar elementos asexuados) y ánade, con el sentido de pato, "procedente del femenino latino ANAS, -ATIS, que experimentó un cambio de género en el que parece haber influido el uso de la variante $e l$ del artículo por razones morfofonológicas" (113).

Al lado de estos, muchos de los sustantivos catalogados por la tradición como ambiguos en cuanto al género empiezan a dejar de serlo según la RAE, debido a un cúmulo de circunstancias entre las que tienen gran peso las geográficas o la propia naturaleza léxica de los sustantivos así valorados. En ese sentido, la ambigüedad de voces como duermevela, apóstrofe, herpes, áspid ha ido desdibujándose con el tiempo: hoy en día, la primera se usa en femenino y las tres últimas, en masculino. También prefieren el femenino los vocablos cochambre, dote, enzima y pelambre, con variaciones bien documentadas diacrónicamente a ambos lados del Atlántico que poco a poco van desapareciendo.

A veces una de las dos concordancias muestra preferencias sobre la otra, tal vez por razones de uso culto o porque la repudiada por la norma estándar pervive en el registro popular (Alcina y Blecua, 1984: 525; Gómez Torrego, 1998: 41). Así, en el español americano, maratón y armazón se estiman como femeninas, mientras que el español europeo muestra sus inclinaciones por el masculino. Lo mismo sucede con interrogante o macro, acortamiento de macroinstrucción ${ }^{1}$, que es un ejemplo ilustrador, además, de cómo las palabras acortadas suelen mantener el género de las bases que las originan.

A esta nómina añade la Academia algunos casos en los que el número condiciona la elección del género, como el sustantivo arte, considerado ambiguo

\footnotetext{
1 "Secuencia de instrucciones que se realizan automáticamente con una sola orden" (DLE, ss. vv. macro, macroinstrucción).
} 
desde el Diccionario de Autoridades hasta la última versión del diccionario académico de 2014 en todas sus acepciones, pero con especialización de uso para uno u otro género en correspondencia con el adjetivo que le sigue o, como indica la gramática de la RAE, con el hecho de que estas denominaciones se empleen o no como expresiones designativas (NGLE: 15-116). Este sustantivo suele formar su plural en femenino (las artes, las bellas artes, las artes marciales) sin excepciones. Manifiesta, pues, una oposición formal con valor semántico apoyada en diferencias entre el singular y el plural, el masculino y el femenino (Alarcos, 1994: 62; Gómez Torrego, 1998: 41).

En algunos de los elementos que conforman el inventario de los sustantivos de género ambiguo en español, la Academia observa cruces de factores morfológicos (por ejemplo, la alternancia de número) y semánticos (con variaciones diatópicas) en la elección del masculino o el femenino en voces como lente, siempre femenina en el español europeo, con el significado de 'pieza de cristal transparente que se usa en los instrumentos ópticos' o como 'lente de contacto', y ambigua en el americano con una notable inclinación, dentro de esta ambigüedad, por el masculino para ambas acepciones (NGLE: 116). Solo cuando se emplea como sinónimo de gafa "se suele usar en masculino plural en todas las áreas hispanoamericanas" (116), aunque, como es de sobra conocido, en el español europeo esta forma masculina y plural no es equiparable al sustantivo femenino gafa y su variante gafas.

Para reforzar la idea de que el género es entre los hispanohablantes una cualidad inherente al sustantivo es preciso observar que no son habituales los sustantivos que, "usados con un mismo sentido y en una misma construcción, pueden considerarse ambiguos para una misma comunidad lingüística en un período determinado", que es lo que ocurre con tanga, femenino en América y masculino en España, o bikini-biquini, femenino en el Río de la Plata y masculino en el resto del mundo hispano (NGLE: 116). Apoyan estas consideraciones otros testimonios de ambigüedad de género como la que se deriva de miasma, aguachirle, apócope, apoteosis, aula, comezón, hemorroide, índole, lumbre, parálisis y porción, además de agravante, atenuante, condicionante, eximente, invariante y resultante, que muestran preferencias por uno u otro género en relación con cuestiones geográficas o con el uso que se hace de ellas en determinados sociolectos (NGLE: 116; Gómez Torrego, 2005: 86). En el mismo grupo se incluyen los sustantivos sartén y sauna que "son femeninos en el español europeo, pero alternan ambos géneros en el americano" (NGLE: 117). Finalmente, otras muchas voces del español general presentan variaciones diacrónicas de género que, en algunos casos, han llevado a considerarlas como ambiguas (aceite, alambre apéndice, apocalipsis, arroz, avestruz, detonante, fantasma, tequila, vinagre y vislumbre) o han modificado su género a lo largo de los siglos (puente, color, femeninas en el español medieval y clásico, y ambiguas todavía hoy 
en algunas áreas del español, sobre todo en registros informales). Otros casos de ambigüedad afectan a pijama, doblez, aguafuerte, casete (NGLE: 118-119), que los hablantes, según su procedencia geográfica, usan en masculino o en femenino.

De la síntesis anterior se infiere que el sustantivo sartén no es tomado como ambiguo en sentido estricto por la Real Academia Española, porque las preferencias de género que muestra en el español actual están condicionadas por factores geográficos, con predominio del femenino en España y con alternancia de ambos géneros en el español americano, o diastráticos, si se tiene en cuenta que en muchos estudios se hace referencia al nivel popular en el que la variante masculina encuentra su principal acomodo. Ya Andrés Bello, en su Gramática de la lengua castellana, incluyó sartén entre los sustantivos femeninos acabados en $-n$, sin apuntar ningún dato acerca de su posible ambigüedad frente a otros, como margen, que sí es "ambiguo en singular y comúnmente femenino en plural" (Bello, 1988: 240). A aclarar las circunstancias que han motivado esta variedad de usos se dedicarán las páginas que siguen.

\section{ORÍGENES Y EVOLUCIÓN DEL SUSTANTIVO SARTÉN EN ESPAÑOL}

El género femenino del sustantivo sartén podría justificarse por razones etimológicas, a partir del acusativo de SARTAGO, -INIS, que era femenino en la lengua de Roma. Aunque en el español actual, con las consabidas excepciones, el género masculino se manifiesta con la terminación de los sustantivos, adjetivos $\mathrm{y}$ algunos determinantes en - $o$ y el femenino en $-a$, el género de los sustantivos latinos no estaba expresado de manera tan clara en las declinaciones. Pese a ello, se tiende a afirmar que los nombres femeninos terminados en - $a$ provienen de la primera declinación latina y de algunos neutros plurales, mientras que los masculinos pudieron originarse a partir de sustantivos latinos terminados en $-u s$, muchos de ellos de la segunda y la cuarta declinaciones, que, en posición final, evolucionaron hacia la - $o$ tomada hoy como morfema predominante en la expresión del género masculino (Vila Puyol, 1992; Alvar y Pottier, 1983: 39-40; Echaide, 1969; Dardel, 1965). Estas soluciones se justifican por las correspondencias entre el género y las desinencias nominales que, sin embargo, no siempre se cumplieron, como explica Ernout (1953) cuando habla de la concordancia como única norma, y remite a las concepciones naturalistas de la distribución del género en indoeuropeo, para mostrar la arbitrariedad con la que algunos sustantivos definieron su género gramatical en el paso del latín al romance.

Además, el castellano convirtió en masculinos algunos sustantivos femeninos que en latín terminaban en -AGO, -AGINIS (por ejemplo, cartílago, putríla- 
go, mucílago) o -IGO, -IGINIS (vértigo, impétigo, lentigo), mientras que otros como sartén, derivado del acusativo singular de SARTAGO, SARTAGINIS, es decir, de la variante SARTAGINEM que perdió la -M desinencial, conservaron su género etimológico, en este caso el femenino. La misma suerte corrieron otros nombres como imagen, calígine, cartilágine, vorágine.

Corominas y Pascual (DCECH, s. v. sartén) remiten al latín SARTAGO, -AGINIS y leen por primera vez el vocablo en castellano en el Libro de Apolonio (hacia mediados del siglo XIII). Por el CORDE se descubre que en este primer registro el vocablo se usa en plural sin determinante ("aguisar los comeres, sartenes e calderas") ${ }^{2}$; después aparecen nuevas recurrencias, siempre en femenino y plural, en fragmentos de la General estoria de Alfonso X el Sabio, que ofrece, según los registros de la base de datos diacrónica de la RAE, seis muestras en descripciones culinarias. También se encuentra en el anónimo Libro de los caballos (1275), en un tratado sobre halconería de hacia 1300 y en un testamento leonés de 1316, y es habitual en escritos análogos datados en los siglos XIV y XV con valores idénticos. La literatura ofrece más ejemplos de la popularidad de este término en el Libro de buen amor de Juan Ruiz (13301343) y, un siglo después, en la Visión deleytable de Alfonso de la Torre, en ambos casos incluida la voz dentro de enumeraciones de utensilios de cocina.

De sarten/sartén, femenino singular, proporciona el CORDE ochenta y seis ejemplos en treinta y seis documentos, desde los orígenes del castellano hasta 1500, todos ellos asociados a determinantes o adjetivos femeninos. En textos posteriores prevalece el mismo género: entre 1500 y 1900, se encuentran ochocientos cincuenta y seis casos del femenino sarten/sartén en textos de distintas tipologías. La forma sartén femenina domina en los numerosos registros posteriores a estas fechas en escritos procedentes tanto de España como de Hispanoamérica (Ecuador, Argentina, El Salvador, Venezuela, Cuba, Honduras, Perú, Colombia, Guatemala, México, entre otros, ofrecen muestras claras de este uso).

Los datos anteriores dejan fuera de dudas que el sustantivo sartén se usa como femenino en la mayor parte del dominio geográfico del español y que su posible ambigüedad está asociada a cuestiones diatópicas, pero no es propia del español general, como sugería Rosenblat (1947 y 1948) al afirmar que este sustantivo, hoy femenino, se usa en la actualidad como masculino en muchos lugares de Hispanoamérica.

En la misma línea, Corominas y Pascual defienden que "hoy se emplea sartén como masculino en América" (DCECH, s. v. sartén); consideran que, con este género, es "absolutamente general en la Argentina", y así se registra tam-

${ }^{2}$ El ejemplo procede de la base de datos CORDE (sartenes) de la Real Academia Española; del uso de este vocablo en plural proporciona diecisiete casos en doce documentos entre $1240 \mathrm{y}$ 1500 , todos ellos usados en femenino. 
bién en Chile, Colombia, Honduras, México y "en todos los países del Nuevo Mundo". Estos datos, contrastados con otros procedentes de monografías hispánicas, sirven a Corominas y Pascual para añadir (siguiendo a Cuervo, 1907: 119) que "también se oye en Asturias" y que, además, "lo emplean los judíos españoles", tesis que encuentra equivalencias en la de Pedro Henríquez Ureña, para quien el uso del sustantivo sartén en masculino "es frecuente en toda España”.

Corominas y Pascual rebaten estas interpretaciones, por la supremacía, según ellos, de la variante femenina en toda la geografía española, tanto en Madrid, Aragón y la Andalucía oriental como en zonas de predominio absoluto del género etimológico de sartén, o en las monografías dialectales de Lamano, sobre Salamanca; García Lomas, sobre Cantabria y la de García Rey, centrada en la comarca leonesa de El Bierzo, que son las fuentes que citan para interpretar este ejemplo de variación diatópica. Para la Andalucía occidental acuden al testimonio literario de Fernán Caballero, "que escribió la sartenaja en un pasaje de tono popular". En otras variedades románicas que han conservado derivados del latín SARTAGO, -AGINIS (portugués, dialectos occitanos e italianos) también se usa el género femenino que, por otra parte, es el habitual en la literatura clásica española, documentado en textos del Marqués de Santillana, Juan de Valdés, Sebastián de Horozco, Mateo Alemán, Cervantes, Tirso de Molina, Correas, Agustín de Salazar y otros grandes escritores del Renacimiento y de los Siglos de Oro, según los registros de Cejador que maneja Corominas.

Ante este predominio de la solución etimológica, Corominas y Pascual identifican el género masculino registrado en países de América y en el dialecto asturiano como el resultado de un proceso de falso análisis del artículo similar "al que condujo de la yunque a el yunque, pasando por l'ayunque", cambio atestiguado por Cuervo (1907: 116) en la Historia general y natural de las Indias (1526), de Gonzalo Fernández de Oviedo, que escribe el asartén (DCECH, s. v. sartén) en el siguiente fragmento:

¡Oh capitanes, que predicáis de estas tierras que vais a poblar o a saltear e destruir, pregonando conversión e baptismo, e destruyendo la tierra en que entráis e a los naturales della, e matando a los cristianos que con vosotros lleváis embelesados e atronados de vuestras promesas, fritas en el asartén de los desventurados tristes que os escuchan e creen, sin saber dónde vais, sin ninguna certinidad ni expiriencia de las provincias donde los lleváis a padescer tantas e tan nuevas maneras de muertes! (CORDE, asartén).

Siguiendo los planteamientos de Rosenblat (1949: 21), en el uso del artículo ante determinados sustantivos hay un componente de "inestabilidad genérica" no limitado solo a aquellos que comienzan por $a$ - tónica. Esta inestabilidad se da preferentemente en el singular, por lo que puede afirmarse que en el plural hay "mayor fijeza" (Rosenblat, 1949: 32). Las reflexiones del hispanista polaco 
afincado en Argentina no son fáciles de aplicar a términos como sartén, que comienza por $s$-, consonante poco dada a desarrollar elementos vocálicos de tipo protético (salvo cuando se trata de una $s$ - líquida latina). Pero sí podrían ser equiparables a algunas formas llanas o paroxítonas que, sin comenzar por $a$-, terminan en sílaba átona trabada por consonante y han desarrollado vacilaciones de género similares a las de sartén. Voces como bácar registran la variante bácara, nácar > nácara, ambas acomodadas al femenino, presentes en algunas hablas leonesas en los años cincuenta del pasado siglo (p. 29), en cuya construcción fonética descubre Rosenblat analogías con voces como ánsar o ámbar.

Decimos que podrían ser equiparables pero solo en cuanto a su estructura, porque en textos castellanos del siglo XVI se encuentra la variante sartena en dos inventarios de bienes confiscados a los moriscos del Reino de Granada, ambos anónimos: "Dos orones de sparto. Una sartena y trébedes" (1559) y "Una caldera. Una sartena de hyerro. Un molinico. Unas scudillas" (1559). Frente a los ejemplos señalados por Rosenblat, en estos dos no se adivina el falso análisis del artículo para justificarlos, sino un proceso de hipercaracterización morfológica del femenino, que añade la $-a$ final a la consonante para afianzar así el género, por analogía con la mayor parte de los sustantivos femeninos de la lengua española terminados en $-a$. No es un caso aislado en la evolución de la lengua española y de otras variedades peninsulares, como se comprueba al contrastar esta forma con vocablos similares procedentes de voces de estructura idéntica en latín, como PLANTAGO, -INIS, que dio llantén en castellano general y también plantaina $^{3}$ (interpretada por Corominas y Pascual como aragonesismo del $D R A E)$ y otros ejemplos fáciles de localizar en textos de todas las épocas: llantaina en un tratado de patología de 1500 (CORDE, llantaina) y en el Diccionario General de la Lengua Asturiana, junto a la variante occidental chantaina (DGLA, s. v. llantaina) (con el paso pl- > ch- inicial, tan característico del gallego-portugués y de sus fronteras); o plantaina, también en asturleonés, usada, como las variantes anteriores, solo en femenino.

Con estos datos se puede afirmar que el sustantivo sartén ha mantenido en castellano su género etimológico femenino y que su terminación en sílaba tónica trabada por una consonante nasal no ha sido inconveniente para reforzar esta condición, como se desprende de la forma sartena ya analizada. Pero esa misma terminación y la vocal $-e$ han podido favorecer el desarrollo de una variante masculina que funciona en la lengua de la misma forma que la totalidad de los

${ }^{3}$ Llantén Del lat. PLANTÂGO, -NIS. 1. m. Planta herbácea, vivaz, de la familia de las plantagináceas, con hojas radicales, pecioladas, gruesas, anchas, ovaladas, enteras o algo ondeadas por el margen, flores sobre un escapo de 20 a $30 \mathrm{~cm}$ de altura, en espiga larga y apretada, pequeñas, verdosas, de corola tubular en la base y partida en cuatro pétalos en cruz, fruto capsular con dos divisiones, y semillas pardas elipsoidales, que es muy común en los sitios húmedos, y el cocimiento de sus hojas se usa en medicina (DLE, ss. vv. llantén y plantaina). 
sustantivos masculinos terminados en -én (arcén, andén, edén, almacén, terraplén, vaivén, rehén) acompañada de determinantes y calificativos masculinos. Ya lo señaló Rufino José Cuervo, en sus Apuntaciones críticas sobre el lenguaje bogotano (1907: 119): "Sin duda que el ser masculinos todos los sustantivos agudos en -én es la causa de que los bogotanos (y muchísimos americanos) digamos "que limpien el sartén", "lleven un sartén". En los libros castellanos solo se halla la sartén".

La distribución geográfica de los dos géneros y las diferencias diacrónicas (en lo antiguo no se registran casos de alternancia) hacen difícil aceptar que sartén sea un sustantivo de género ambiguo, como se verá a continuación.

\section{El SUSTANTIVO SARTÉN EN LOS DICCIONARIOS DE LA LENGUA ESPAÑOLA}

El uso literario del sustantivo sartén se ve respaldado por su presencia en los repertorios de vocabulario de la lengua española ${ }^{4}$ desde los tiempos de Alonso de Palencia (1490) hasta nuestros días. El humanista y lexicógrafo soriano la define como voz proveniente de SARTAGO, que es sartén en castellano, y "dize se del son que faze enella el azeyte quando fierue al fuego, es vasija de fierro o de cobre" (Nieto y Alvar, 2007: 8760). Nebrija la recoge en 1495 con el sentido de "sarten para freir" equivalente al vocablo latino SARTAGO, -INIS, y esta explicación sirve de base a la mayoría de los diccionarios bilingües de los siglos XVI y XVII (Casas 1570, Percival 1591, Palet 1604, Oudin 1607, Vittori 1609, Minsheu 1617, Franciosini 1620) que recogen la voz sartén sin mencionar su género.

Sebastián de Covarrubias (1611) la define como continuadora, desde el punto de vista semántico, del vocablo latino SARTAGO y reproduce un proverbio en el que, acorde con su género etimológico, la voz aparece utilizada en femenino: "dixo la sarten a la caldera, quítate alla negra". Francisco Sobrino (1705), en su Diccionario nuevo de las lenguas española y francesa, indica que sartén es un sustantivo femenino equivalente al francés "poele à frire quelque chose". Su testimonio resulta muy interesante porque revela uno de los primeros indicios de las alternancias entre el femenino y el masculino en el uso común de este vocablo: tras la definición que se acaba de reproducir incluye la expresión "fruta del sartén", que refleja cómo la preposición de se contrae con el artículo en su forma masculina ( $d e l)$. El ejemplo pone de manifiesto que la

\footnotetext{
${ }^{4}$ Todas las referencias a los diccionarios antiguos del español, desde Nebrija hasta la edición de 1992, provienen del NTLLE. La información obtenida de esta consulta se ha contrastado con la de Nieto y Alvar (2007: 8760-8761).
} 
alternancia de los dos géneros coincide en una misma definición en tiempos en los que apenas hay registros escritos de esta variedad. De ahí su enorme interés.

El Diccionario de Autoridades (1739) lo presenta directamente como un sustantivo de género femenino; las citas que le sirven para ilustrar sus usos literarios son coherentes con esta etiqueta, tanto en el singular como en el plural: "por las sartenes donde algo se freía"; "dixole el cazo a la sartén, quítate allá no me tiznes"; "tener la sartén por el mango"; "un ojo a la sartén, y otro a la gata". También lo son las voces derivadas de sartén y las explicaciones que se dan sobre sus significados: sartenada ("lo que de una vez se puede freír en la sartén") y sartenazo ("el golpe que se da con la sartén"). Este primer repertorio académico sienta las bases de la definición que se da del vocablo en las ediciones sucesivas del diccionario (1780, 1783, 1791, 1793), algunas de las cuales van incorporando acepciones nuevas o ilustrando sus sentidos con refranes y frases hechas que ponen en evidencia la fortaleza del femenino en su uso general durante todo el siglo XVIII.

Esteban de Terreros y Pando (1788) ofrece una definición similar y añade dos variantes diminutivas como entradas independientes, que también resultan interesantes para reforzar el uso femenino del vocablo en sus derivados: sartenilla y sartenita, como "sartén pequeña". En esta misma línea, el diccionario académico de 1803 y los de 1817, 1822, 1832, 1837, 1843 y 1846 reproducen los dos diminutivos aducidos por Terreros e incorporan otros, sarteneja y sartenica, que se definen como sustantivos femeninos diminutivos de sartén (s. f. d. de sartén). Esta relación de diminutivos se repite en los diccionarios de Vicente Salvá (1846) y Ramón Joaquín Domínguez (1853); el diccionario académico de 1869 añade nuevos derivados con interfijo para los diminutivos usuales: sartencica, sartencilla, sartencita, siempre femeninos como se deduce de su vocal final. Así pues, los diccionarios académicos del siglo XIX y otros de diferentes autores (Zerolo 1895), y también los de principios del XX (RAE 1914 y 1925, Alemany Bolufer 1917, Rodríguez Navas 1918), mantienen la definición y los usos tradicionales asociados al género femenino de este término y de sus derivados.

Para encontrar la primera mención al uso masculino del vocablo habrá que llegar al Diccionario Manual e Ilustrado de la Lengua Española de la Real Academia en su edición de 1927. Tras definir el concepto en consonancia con la tradición anterior, se añade un dato interesante porque refleja que el uso del género masculino está estigmatizado como barbarismo en el primer cuarto del siglo pasado y muestra recurrencia en áreas del español americano ("Es barbarismo usar en masculino esta voz, como hacen en algunas regiones de América"). Esto significa que la alternancia de géneros es reconocida como "vicio del lenguaje, que consiste en pronunciar o escribir mal las palabras, o en emplear vocablos impropios", que es la definición que el mismo diccionario da del 
sustantivo barbarismo. Las ediciones del diccionario usual de 1936, 1939, 1947, 1956, 1970 y 1984 omiten estas apreciaciones, pero el manual de 1950 las mantiene, aunque elimina la marca geográfica hispanoamericana del uso impropio del género masculino para añadir, en las versiones de 1985 y 1989, que "en muchos lugares de España y América es masculino". La apreciación sociolingüística de la Academia determina que también Aniceto de Pagés (1931) haya tomado el uso del masculino de sartén como un barbarismo americano en su Gran diccionario de la lengua castellana. Por fin, en 1992, la Real Academia Española especifica en su diccionario usual que la voz sartén, femenina, "en muchos lugares de España y América es masculina". Años después, el Diccionario de Americanismos de la Real Academia Española y la Asociación de Academias de la Lengua Española (2010, s. v. sartén) cita Honduras, El Salvador, Nicaragua, Costa Rica, Cuba, República Dominicana, Puerto Rico, Venezuela, Ecuador, Bolivia, Chile, Paraguay y Uruguay entre los países americanos en los que el género masculino es habitual; en esta nómina llama la atención la ausencia de México, donde, como se verá, el masculino tiene una fuerte presencia en todos los registros y niveles del habla. Aparte, menciona la forma femenina sartena, habitual en El Salvador, como "cacerola de barro grande y con asas para cocer alimentos" (s. v. sartena), testimonio que podría servir para ilustrar que el sartén y la sartena justifican, en determinadas zonas de El Salvador, una alternancia de género basada en el tamaño del objeto (que en algunos estudios gramaticales se identifica como "género dimensional"): cesto/cesta, jarro/jarra, huerto/huerta, charco/charca. Al tratarse de una combinación registrada solo en este país centroamericano, no es posible extenderla a otras áreas vecinas para trazar una isoglosa que pudiera explicar esta variación por cuestiones morfológicas y semánticas.

\section{El GÉNERO DE SARTÉN EN EL ESPAÑOL ACTUAL}

El Corpus del Español del Siglo XXI (CORPES XXI) de la Real Academia Española, que puede iluminar las conclusiones sobre la variación que afecta hoy al género de sartén, lo identifica siempre como un "sustantivo femenino singular común", incluso en ejemplos que muestran con claridad su uso en masculino con determinantes y adjetivos de este género, como se observa en algunos de los primeros registros que ofrece, todos ellos procedentes de textos de tema gastronómico datados en México en 2001 y, en especial, del volumen coordinado por Mariliana Montaner, Alquimias y atmósferas del sabor. Alta gastronomía de doña Carmen Titita:

Caliente el aceite o manteca y fría los frijoles hasta que estén chinitos o que se vea el fondo del sartén. Dele forma de molote y sirva muy caliente. 
Ponga a dorar el fideo en un sartén con aceite y escúrralo muy bien.

Tueste las pepitas en un sartén o comal, cuide que no se queme.

Ponga en un sartén un cuarto de taza de aceite de oliva y fría con cuidado.

Al poner las tiras en el sartén frunza el centro para formar un moñito (CORPES XXI, sartén).

Entre 2001 y 2012, el CORPES XXI ofrece 1923 registros de uso del sustantivo sartén distribuidos en 660 documentos representativos de los distintos países del ámbito hispanohablante europeo y americano que, a pesar de la generalización apuntada en las etiquetas con las que la RAE los identifica en su corpus, no siempre se usan en femenino, sobre todo en textos procedentes de México y, de forma más restringida, en otros localizados en diferentes latitudes del continente americano (Chile, Guatemala, Venezuela), sin dejar de lado la comunidad hispana de los Estados Unidos, donde la recurrencia al masculino resulta bastante significativa.

De la cifra total de casos, corresponden a España 917 repartidos en 254 documentos entre los años 2001 y 2012. En ellos se refleja que el género dominante en el uso del sustantivo sartén es el femenino en todo tipo de textos y autores. Solo en un documento de 2006 se encuentran dos testimonios del uso del masculino ("saltear en un sartén con una cucharada de mantequilla" y "en un sartén poner más aceite de oliva virgen"), ambos en un tratado culinario del madrileño Darío Barrio, Las recetas de "Todos contra el chef" (2006). La falta de registros similares en otras fuentes hace difícil interpretar el origen de esta única presencia del masculino entre los casi mil documentos españoles que prefieren el femenino. Tampoco la base de datos académica CREA aclara las dudas cuando ofrece un único ejemplo peninsular del masculino tomado de los Cuentos extremeños de Marciano Curiel Merchán (1944), al lado de otros dos testimonios similares, uno cubano y otro mexicano: "el tocino de untarse mi abuela las almorranas, que tenía aquí en un sartén", dice la versión citada por el corpus. El dato procede de la segunda edición del libro, de 1987, y puede leerse como una errata de impresión, porque la primera edición de estos cuentos (publicados en 1944 por la Biblioteca de Tradiciones Populares del CSIC) muestra que es el femenino el género empleado por el maestro y folclorista extremeño en la transcripción de un relato de contenido humorístico, "El escrupuloso", donde una joven guarda el tocino que usa su abuela para curar las hemorroides en una sartén (p. 472)

\footnotetext{
${ }^{5}$ La misma base de datos CREA proporciona dos ejemplos más del uso del masculino sartén: el primero procede de la comedia de Jorge Ibargüengoitia, La lucha con el ángel. Pieza en tres actos, de 1955: "Gil tiene un sartén en la mano". El segundo se halla en un ensayo del autor cubano Rómulo Lachatañaré, El sistema religioso de los Lucumi y otras influencias africanas en Cuba (1039-1952): "un collar rojo, un sartén, una canasta de plátanos".
} 
A Hispanoamérica corresponden los restantes 997 casos distribuidos en 406 documentos de diferentes tipologías, con predominio de los de tema gastronómico, ámbito en el que el sustantivo que nos ocupa encuentra su principal contexto semántico. Tras una búsqueda exhaustiva, con el apoyo de las herramientas que proporciona la base de datos académica, se observa que en la mayor parte de las regiones del español americano predomina también el uso del género femenino cuando el sustantivo aparece precedido por determinantes o en concordancia con adjetivos que portan dicho género. De estas consideraciones se han excluido los abundantes casos en los que el sustantivo sartén se cita en singular o en plural sin determinantes, ni cuantificadores, ni adjetivos, aunque en muchos de ellos, instalados en textos en los que predomina el femenino, es fácil adivinar la preferencia por el uso de este género. Tales observaciones permiten constatar que en un total de 997 documentos se lee el femenino la/una sartén en 746 ocasiones, el masculino el/un sartén en 142 y el mismo sustantivo en plural o en singular, sin determinación del género, en 109 formas procedentes de todos los países del ámbito americano. Las formas señaladas se distribuyen de modo desigual en los diferentes países, tal y como refleja esta tabla por orden alfabético:

\begin{tabular}{|l|r|r|r|r|}
\hline & \multicolumn{1}{|c|}{ Femenino } & \multicolumn{1}{|c|}{ Masculino } & Sin especificar & Documentos \\
\hline Argentina & $101(90 \%)$ & $3(2,67 \%)$ & $8(7,14 \%)$ & 112 \\
\hline Bolivia & $12(70,58 \%)$ & $2(11,76 \%)$ & $3(17,64 \%)$ & 17 \\
\hline Chile & $36(59,32 \%)$ & $15(25,42 \%)$ & $9(15,25 \%)$ & 60 \\
\hline Colombia & $125(93 \%)$ & $5(3 \%)$ & $6(4 \%)$ & 134 \\
\hline Costa Rica & $1(50 \%)$ & 0 & $1(50 \%)$ & 2 \\
\hline Cuba & $40(80 \%)$ & $4(8 \%)$ & $6(12 \%)$ & 50 \\
\hline Ecuador & $19(82,60 \%)$ & $1(4,34 \%)$ & $3(13,04 \%)$ & 23 \\
\hline El Salvador & $15(78,94 \%)$ & $2(10,50 \%)$ & $2(10,52 \%)$ & 19 \\
\hline Estados Unidos & $5(33,33 \%)$ & $9(60 \%)$ & $1(6,66 \%)$ & 15 \\
\hline Guatemala & $18(58,06 \%)$ & $10(32,25 \%)$ & $3(9,67 \%)$ & 31 \\
\hline Honduras & $4(66,66 \%)$ & 0 & $2(33,33 \%)$ & 6 \\
\hline México & $131(55,70 \%)$ & $66(27,60 \%)$ & $42(17,50 \%)$ & 239 \\
\hline Nicaragua & $5(62,50 \%)$ & $2(25 \%)$ & $1(12,50 \%)$ & 8 \\
\hline Panamá & $3(66,66 \%)$ & $8(25 \%)$ & $1(8,33 \%)$ & 12 \\
\hline Paraguay & $22(87,50 \%)$ & 0 & $3(12,50 \%)$ & 25 \\
\hline Perú & $36(87,80 \%)$ & $2(4,87 \%)$ & $3(7,31 \%)$ & 41 \\
\hline Puerto Rico & $21(80,76 \%)$ & $2(7,69 \%)$ & $3(11,53 \%)$ & 26 \\
\hline Rep. Dominicana & $27(90 \%)$ & $3(10 \%)$ & & 0 \\
\hline Uruguay & $19(55 \%)$ & $4(20 \%)$ & $5(25 \%)$ & 30 \\
\hline Venezuela & $102(85,70 \%)$ & $8(6,72 \%)$ & $9(7,56 \%)$ & 119 \\
\hline
\end{tabular}

TABLA 1.- Distribución del género de sartén en los diferentes países de Hispanoamérica según el CORPES XXI 
Como se puede observar, la mayor frecuencia de ejemplos del masculino sartén se constata en México, con un total de sesenta y seis casos repartidos en doscientos treinta y nueve documentos. Pese a la cantidad aportada, resulta difícil admitir que el masculino sea el género predominante en el país norteamericano, si se tiene en cuenta que las formas relativas al femenino representan algo más del doble. Más al sur, por ejemplo en Chile, las proporciones son similares: treinta y seis ejemplos de uso del femenino frente a quince del masculino, en un espacio en el que cuesta encontrar un continuum geográfico con México capaz de marcar una isoglosa vertical de norte a sur (u horizontal, de este a oeste, para entender las divergencias entre Chile y Argentina) que daría una respuesta a los motivos de ese desequilibrio de recurrencias al masculino entre las áreas septentrionales y las meridionales, orientales y occidentales. Y es que, como indicó Henríquez Ureña (1921), el español de Chile, estandarizado en los modelos de Santiago y Valparaíso, es tan distinto al de sus países vecinos que constituye una zona dialectal propia, separada del resto (Lipski, 1996: 219).

Por otro lado, Guatemala, que comparte casi mil kilómetros de frontera con México en sus límites noroccidentales, muestra dieciocho ejemplos del femenino y diez del masculino, dispersos en textos de tema divulgativo (tratados sobre plantas, sobre gastronomía) y en narraciones modernas, como la de Carmen Alicia Arévalo, Aquí vivo yo (2010), que habla de "un sartén de peltre" y evoca "el sabor que quedaba en el sartén cuando cocinaban los chorizos" en Santo Tomás de Chiché, en plena Guatemala rural, a ciento setenta kilómetros de la capital, donde la escritora y periodista pasó su infancia y asimiló los registros de su lengua materna.

En Estados Unidos se invierten los términos: la proporción de uso del masculino es más elevada que la del femenino (nueve frente a cinco), en quince textos localizados en los estados de California, Florida, Nuevo México, que acogen hoy los mayores asentamientos de población hispana en Norteamérica. Sirvan de ejemplo las instrucciones que la periodista uruguaya Cristina Juri Arencibia da para elaborar una receta de cebolla caramelizada en la sección gastronómica del periódico El Nuevo Herald de Miami (15 de febrero de 2006): "En un sartén grande cocine el ajo y la cebolla, con la mantequilla, hasta que comiencen a acaramelarse".

La misma situación revelan los datos correspondientes a Panamá, con ocho ejemplos de uso del masculino y tres del femenino, entre un total de doce documentos. Uno de ellos contiene una reflexión interesante, porque aparece en un artículo periodístico de 2005 que trata sobre la carestía del petróleo y los abusos de los países exportadores; estos, según el autor del escrito, tienen, "como se dice en el argot panameño, el sartén por el mango y hay claras evidencias de que no lo quieren soltar". El pronombre complemento directo lo, en 
sustitución de "el sartén", refuerza la ventaja del masculino en este enunciado, y poco importa su posible fosilización en un texto marcado desde el punto de vista sociolingüístico (como propio del argot de Panamá).

En la América insular, la República Dominicana proporciona treinta ejemplos del femenino y tres del masculino, en textos datados entre 2007 y 2011; uno de ellos recrea el dicho popular, "tener el sartén por el mango", interesante de nuevo por la lexicalización del uso y por esa mayor fijeza textual asignada a este tipo de enunciados, como acaba de apuntarse.

En el polo opuesto, se descubren tres países para los que las bases de datos académicas no suministran pruebas del masculino: Costa Rica, Honduras y Paraguay. Todos (excepto Costa Rica, representada con dos documentos en la base de datos) ofrecen variadas recurrencias al femenino, similares a las de otros países incluidos en la lista académica de registros modernos que facilita el CORPES XXI. Los demás testimonios de uso del sustantivo sartén en masculino no son equiparables a los del femenino: tres casos en Argentina, frente a ciento tres femeninos es una cifra que revela que la presencia del masculino en el español rioplatense es casi accidental, por mucho que también el CORDE, que ofrece seis ejemplos del sintagma el sartén, localice cuatro casos en Argentina en textos datados entre 1872 (del escritor Hilario Ascasubi) y 1967 (de Avelino Herrero Mayor, profesor y lingüista) y solo dos en México (CORDE, el sartén). El primero de estos textos acredita la interpretación del uso del masculino como un ejemplo de variación diatópica y, sobre todo, diastrática marcada como propia de hablantes de nivel sociocultural bajo en estas áreas del sur americano; aparece en el poema Santos Vega, el payador, conocido también como Santos Vega o los mellizos de la flor, ejemplo de la literatura gauchesca de finales del siglo XIX que recrea un lenguaje desaliñado, repleto de fuerza dramática, en el que irrumpe con naturalidad la variante masculina de sartén:

$$
\begin{aligned}
& \text { Y, echando pringues de grasa, } \\
& \text { al mesmo tiempo plantó } \\
& \text { el sartén con la fritada } \\
& \text { de unos veinte o veintidós } \\
& \text { güevos con cuatro chorizos; } \\
& \text { pero, ni bien colocó } \\
& \text { el sartén sobre la mesa } \\
& \text { cuando ya lo levantó } \\
& \text { más limpio que una patena; } \\
& \text { porque el buitre Masramón } \\
& \text { a cucharadas los güevos } \\
& \text { se los tragaba de a dos. }
\end{aligned}
$$

Por otra parte, Colombia ofrece cinco ejemplos actuales del uso de sartén en masculino (en textos divulgativos, guías de educación para escuelas saluda- 
bles promovidas por el Ministerio de Salud de Bogotá, donde se leen frases como "se tuesta el arroz en un sartén", "en un sartén con tapa calentar la mantequilla", todos ellos procedentes de la capital del país), frente a más de ciento veinte del femenino. Cuba (en un recetario de cocina de Ronaldo Menéndez, de 2005) y Uruguay (en un tratado sobre educación alimenticia de Miguel Cleffi, Coто сото: almuerce y coma por el precio de dos cafés, de 2003) proporcionan cuatro testimonios cada uno de la variante masculina. Los tres países suman trece casos en total entre más de doscientos documentos.

Bolivia, El Salvador, Nicaragua, Perú y Puerto Rico atestiguan el uso del masculino en dos ocasiones (diez referencias suman entre todos), frente al predominio claro del femenino en un total de ciento doce documentos, que recogen textos de diversa tipología. Con una única referencia, cabe citar el caso de Ecuador, donde el femenino (con una veintena de testimonios en veintitrés documentos) es también el género dominante.

El análisis de estas cifras pone de relieve que en el sustantivo sartén se usa mayoritariamente en femenino en el ámbito hispanohablante. Por ello, pese a los abundantes testimonios de su uso en masculino que se pueden encontrar en diferentes áreas lingüísticas de Hispanoamérica, no es posible asignarle la etiqueta de "sustantivo de género ambiguo" o "ambiguo en cuanto al género", como muy bien aclara el Diccionario Panhispánico de Dudas de la Real Academia Española cuando sostiene que en el habla culta general de España este sustantivo es femenino y que su uso en masculino "es muy escaso y se restringe al habla popular de algunas regiones", todas ellas en territorio americano, donde alternan ambos géneros, "con predominio del masculino". Ilustra la definición con dos ejemplos de uso, uno del masculino procedente de la República Dominicana ("«Fregó el sartén y los platos» [Vergés Cenizas, 1980]”) y otro del femenino, tomado de español chileno ("En una sartén quedaban dos colas de iguanas carbonizadas" [Sepúlveda Viejo, 1989])", país donde, paradójicamente, la pujanza del masculino es muy notable (DPD, s. v. sartén).

Con las referencias anteriores, podríamos afirmar que la alternancia entre el género femenino y el masculino del sustantivo sartén representa un tipo de variación diatópica condicionada por la procedencia geográfica de los hablantes: pese a no hallar ejemplos de su uso en Costa Rica, parece que la propensión hacia el masculino es habitual en el español de Norteamérica (con Estados Unidos $\mathrm{y}$, sobre todo, México a la cabeza), irrumpe con firmeza en textos centroamericanos (de Guatemala y Panamá), llega al Cono Sur y se instala en Chile, aunque apenas asoma en Argentina y en otras latitudes meridionales del continente, siempre en escritos que ocultan testimonios de variación diafásica y diastrática asociada al contexto comunicativo y al nivel sociocultural de los hablantes.

Urge, por ello, averiguar en qué momento pudo producirse ese intercambio de géneros y en qué medida los textos antiguos del español americano dan tes- 
timonio de estas alternancias. El Corpus Diacrónico y Diastrático del Español de América (CORDIAM), que procesa información de escritos datados desde los orígenes de la conquista (1494) hasta los primeros años de la independencia de las repúblicas americanas (1905), ofrece cuatro testimonios del uso del sustantivo sartén, tres femeninos, procedentes de Chile, Cuba y México, y uno masculino, extraído de una carta anónima escrita el 27 de diciembre de 1827 al director del periódico El Hambriento de Santiago de Chile:

Dirijime á uno de ellos enfadado, y habiendo oido mis reconvenciones, me dijo: esto es propiamente hablando, "el sarten tras de la olla" vos os llamais el hambriento; y nosotros ¿como nos llamarémos? (CORDIAM, sartén).

El documento anterior muestra el uso del masculino asociado a una sentencia con múltiples variantes en español general, como "Dijo la sartén a la caldera: ¡quítate allá, ojinegra!", "Dijo la sartén al cazo: japártate, que me tiznas!", "La sartén le dijo a la alcuza: retírate, que me ensucias", y otros muchos que sirven como recriminación para dos personas que, siendo igual de ruines, se echan en cara sus defectos. Esta circunstancia podría justificar el predominio del género masculino por el alto grado de fijación formal del texto en el que se integra. Es un nuevo ejemplo de variación diacrónica fortalecida por la variación diastrática que vincula el uso del masculino al registro popular del habla en el que estos textos suelen perdurar. Al tratarse de un escrito proveniente de Chile, también la variación diatópica, que ha mostrado en páginas anteriores la vitalidad del masculino sartén en la patria de Pablo Neruda, serviría para entender este modelo de alternancia gramatical en un texto decimonónico.

Los otros tres ejemplos son interesantes también desde la perspectiva diacrónica, a pesar de que no revelan alternancias de género. El primero de ellos procede de un inventario de bienes de Sebastián de Mendizával, mayordomo del Hospital de Santiago, adscrito a la Capitanía General de Chile (Virreinato de Perú) y datado en 1597. Es un testimonio muy temprano si se tiene en cuenta que la conquista del territorio que hoy ocupa Chile comenzó en 1540 bajo el caudillaje de Pedro de Valdivia y que la capital, Santiago, se fundó un año después (Lipski, 1996: 220). Recordemos que el primer registro anotado de vacilación en castellano se encontraba en el Diccionario nuevo de las lenguas española y francesa, de Francisco Sobrino (1705), incluido en la expresión "fruta del sartén", testimonio claro de que la alternancia entre los dos géneros coincide en la misma definición del vocablo en una fecha en la que las pruebas escritas de esta variedad son excepcionales.

El testimonio cubano podría merecer idénticas consideraciones: se inserta en un texto de 1629 adscrito a la Capitanía General de Cuba y trata sobre la entrega del Hospital de San Felipe el Real de La Habana a los hermanos de la congregación de San Juan de Dios; el vocablo forma parte de la descripción de 
los "trastes de cosina" que alberga el edificio y muestra claramente el uso de la forma femenina de sartén sin vacilación de género. El último texto (mexicano, datado en 1640) procede de la Capitanía General de Yucatán y corresponde "a una lista de compra que estaba entre los papeles de Juan de la Cámara Aldana", "una espumadera, una cuchara, una sartén grande" en la relación de "herramienta que se ha de comprar para la coçina". Queda claro que, por lo menos a mediados del siglo XVII, los textos americanos tampoco ofrecen ejemplos de la alternancia de géneros que nos ocupa.

Los textos del CORDIAM abarcan dos áreas importantes desde la perspectiva actual de la vacilación morfosintáctica analizada (México y Chile). Esta muestra exigua de datos pone de relieve que la cuarta parte de los testimonios antiguos de la alternancia de géneros en el sustantivo sartén corresponde al masculino. Aunque el abanico geográfico que abarcan los datos proporcionados por este corpus no es amplio ni exhaustivo (porque deja más del ochenta por ciento de los países sin representación) sí que ilumina detalles interesantes sobre la frecuencia de uso de la variación de géneros y sobre su distribución. También habla sobre la confluencia de los dos géneros en un mismo espacio geográfico (Chile, en este caso), simétrica con la situación que ofrecen los corpus de textos modernos analizados en páginas anteriores.

Por su parte, el corpus PRESEEA (Proyecto para el estudio sociolingüístico del español de España y de América) consigna otros seis ejemplos en textos orales del uso de sartén en masculino, entre un total de veintidós registros de los cuales quince son femeninos y corresponden a la variedad europea del español. Los masculinos provienen de Caracas (un solo caso, grabado el 9 de agosto de 2004, "traíamos un sartén eléctrico", en boca de una mujer nacida en 1970) y los cinco restantes, de México: "luego en un sartén echo mantequilla" (4 de abril de 2008, mujer de Monterrey, con estudios primarios); "pongo en un sartén mantequilla", "lleno todo el sartén de puro pan" y "en el sartén vuelvo a hacer lo mismo" (11 de febrero de 2008, hombre de Ciudad de México, con estudios básicos); "los hace con mantequilla de puerco y el sartén está ahí siempre", "deja el sartén en la estufa" (14 de marzo de 2008, hombre joven, también de la capital mexicana, funcionario). Otra vez México ofrece muestras abundantes de la variedad que nos ocupa, tanto en el habla femenina como en la masculina y en sujetos de diversa procedencia social. Se cumplen en la muestra algunos de los patrones necesarios para obtener resultados fiables en el análisis sociolingüístico (hombres y mujeres, de diferentes edades y niveles socioculturales, todos urbanos), pero resultan insuficientes para extraer de ellos resultados concluyentes, por la falta de representación de la mayoría de las naciones hispanoamericanas. Una deficiencia que, a medida que se complete el corpus, podrá resolverse y arrojar mayor número de formas para ofrecer una imagen cabal de esta variación. 
A llenar este vacío pueden contribuir modelos de estudio como el coordinado por Quesada Pacheco (2013), sobre El español en América Central: nivel morfosintáctico, que interpreta datos tomados de los atlas lingüísticos centroamericanos para describir con ellos el español de Belice, Guatemala, El Salvador, Honduras, Nicaragua, Costa Rica y Panamá. Sus reflexiones sobre la morfología nominal comienzan con el análisis de mapas que interrogan por el concepto sartén para averiguar sus vacilaciones de uso en el espacio señalado. Belice (2013: 26-27) revela una inclinación clara por el femenino (66\%), seguido del masculino (22,5\%), en un contexto en el que el $12,5 \%$ de la población alterna los dos géneros. Guatemala muestra, en el $89 \%$ de los casos, sus preferencias por el género masculino al que la autora del estudio, Chavarría (2013: 69), considera "forma canónica", frente a la femenina, que sería la "no canónica”. En El Salvador domina la variante femenina, "con un reducido margen de preferencia por el sartén" entre los hablantes de la primera generación, según explican Quesada y Rivera (2013: 145-146). En el caso de Honduras, la forma estándar es la masculina, usada por el 83,33 \% de los informantes entrevistados, frente a un $16,66 \%$ que opta por la variante femenina, según explica Hernández Torres (2013: 195-196). Más al sur, Nicaragua ofrece muestras del masculino "en casi todo el país", salvo en cuatro departamentos (Chinandega, León, Jinotega y Bluefields), que prefieren el femenino con algunas diferencias entre el habla de los mayores, más apegados al masculino, y la de los jóvenes, donde el femenino goza de mayor expansión (Díaz y López, 2013: 229-230). Por su parte, Costa Rica prefiere la variante femenina (Castillo Venegas, 2013: 303) y Panamá, la masculina (Quesada y Tinoco, 2013: 344).

Los datos aportados por este estudio matizan en parte las conclusiones extraídas de las bases de datos del español. Son coherentes con la situación que muestra Costa Rica, sin referencias al masculino en el CORPES XXI, o El Salvador, con escasas recurrencias; pero no lo son con respecto a Honduras, donde el estudio dirigido por Quesada Pacheco, que se inspira en los principios teóricos y metodológicos de la geografía lingüística a partir de registros orales, pone de manifiesto que la variante masculina del sustantivo sartén goza de gran prestigio entre todo tipo de hablantes. Otra vez hay que insistir en la necesidad de contrastar los fenómenos para obtener una imagen real de la variación en el habla.

\section{REFLEXIONES FINALES}

Los datos anteriores proceden de obras lexicográficas, de monografías sobre el español americano y de la interpretación de bases de datos léxicas inspiradas en textos escritos y orales. Si volvemos la vista hacia otro tipo de fuentes más 
próximas a los usos del habla coloquial (las redes sociales, los blogs o los foros internáuticos), podríamos reorientar en parte nuestras conclusiones. Una búsqueda sencilla en Google permite hallar centenares de ejemplos que muestran la vitalidad actual de este cambio de géneros y también el debate en torno al carácter más o menos apropiado de cada uno de ellos desde una perspectiva sociocultural. Muchas de las opiniones expresadas en los foros esconden reflexiones metalingüísticas valiosas para conocer la actitud de los hablantes hacia este fenómeno de variación lingüística. Por ejemplo, el Wikcionario ("diccionario libre") en su versión hispana apunta que "la forma masculina se ha considerado con frecuencia vulgar o inculta, aunque goza de uso extendido y tradicional, tanto en España como en América"6. La plataforma digital Spoots, que explica que el uso del sustantivo sartén se ha popularizado en masculino "en varios países hispanoamericanos (como Chile, Colombia, Venezuela, Nicaragua, Cuba, Argentina o ciertas partes de España)", deja a cada región la libertad de determinar "si una u otra forma es socialmente aceptada". A pesar de ello, por cuestiones de prestigio sociocultural, sugiere que "la forma correcta" es, sin lugar a dudas, la femenina ${ }^{7}$.

En otro foro lingüístico asociado al diccionario digital WordReference un internauta procedente de la ciudad mexicana de Mérida plantea, el 24 de junio de 2006, la siguiente duda sobre el género del sustantivo sartén:

Siempre he considerado que sartén (la que sirve para freír o cocinar) pertenece al género femenino. Hace poco compré una de éstas y en la caja daba instrucciones para usar "EL SARTÉN". Quisiera conocer opiniones al respecto ${ }^{8}$.

La pregunta obtuvo cincuenta réplicas, algunas acompañadas de consideraciones sociolingüísticas que alimentan la condición de variante diastrática (asociada al nivel bajo de los interlocutores) con la que en muchos momentos de la historia de nuestra lengua se ha distinguido el uso del sintagma el sartén. Desde esta perspectiva, la variante masculina es interpretada como "incorrección" por un hablante argentino, o como "modo de la gente de bajo nivel cultural" por un internauta de Mérida, en México; incluso como una deformación del habla digna de ser corregida ("de pequeña decía el sartén y mis padres siempre me corregían", Buenos Aires) o criticada por su relación con las clases bajas ("concluyo en que seguiré criticando a quienes dicen el sartén") en la península de Yucatán. Pero esta visión social contraria al uso masculino de sartén no es

\footnotetext{
${ }^{6}$ En $<$ https://es.wiktionary.org/wiki/sartén $>$.

${ }^{7}$ En $<$ https://www.spoots.com/educacion/escribe-sarten-sarten>. La misma opinión encierra la web $<$ https://educacion.uncomo.com>, consultada en las mismas fechas.

${ }^{8}$ En $<$ https://forum.wordreference.com $>$.
} 
compartida por todos los hablantes mexicanos ni por aquellos procedentes de otras áreas lingüísticas meridionales donde el masculino aventaja al femenino, según se desprende de las siguientes intervenciones:

En Chile se usa preferentemente el género masculino independientemente del nivel cultural (Santiago de Chile).

Decir "el sartén" se considera más bien un error, pero no se considera por ello que quien lo diga sea una persona inculta (Argentina).

En el caso de el sartén es un término que se repite con mucha frecuencia entre los conductores de TV quienes en su mayoría son capitalinos en México (Mérida, México).

Acá en el norte de México decimos ambas, el sartén y la sartén sin distinción de condición económica o nivel de educación (México).

De los datos ofrecidos por los participantes en esta discusión se desprende que el género masculino mantiene una fuerza extraordinaria en el habla mexicana (sobre todo en la capital del país, incluso entre personas con formación académica, como el periodista al que se refiere un participante del chat) y también en la chilena, situación que coincide, en gran medida, con la ya analizada a partir de las bases de datos léxicas de la RAE y de los diccionarios del español:

En Chile se dice "el sartén" y nunca he escuchado "la sartén" (Santiago de Chile).

Me acabo de enterar [sic] que el género de sartén es femenino (Chile).

Pues yo diría el sartén. Aunque también he escuchado la sartén (Tijuana, México).

Nunca en la Ciudad de México he escuchado "la sartén" — salvo en el dicho "la sartén por el mango". Obvio, tiene género vacilante en el mundo hispanohablante y no es una cosa sociocultural, ya que hasta la gente más culta dice "el sartén", sino dialectal (por región) (Ciudad de México).

Acá en México casi nadie dice "la sartén", salvo en el dicho "saltar de la sartén al fuego", cuando se llega a oír (México).

Algunos hablantes aluden a la alternancia entre ambos géneros, por ejemplo en Perú ("acá decimos la sartén aunque a veces el sartén"), o lo sitúan en regiones muy bien localizadas en el mapa de Hispanoamérica (en Barranquilla, Colombia, "es lo más usual, incluso entre personas de nivel cultural alto"). En el mismo foro, todos los hablantes procedentes de España comentan que el único género que conocen para sartén es el femenino: "sartén es femenino. Tal vez las instrucciones de tu sartén hayan sido mal traducidas del inglés o de otro idioma (cosa, por otro lado, bastante habitual)". 
La duda plateada por el WordReference se resuelve de forma parecida en julio de 2015 en el blog titulado Castellano Actual, dependiente del departamento de Lengua y Literatura de la Facultad de Humanidades de la Universidad de Piura, en Perú: "Si bien el sustantivo sartén es femenino, en Hispanoamérica se prefiere la forma masculina, de allí que se le considere ambiguo. Dependerá del hablante el uso de uno u otro"'. Entre los casi cuarenta comentarios que provocó en su momento esta explicación abundan aquellos en los que los hablantes tildan de "nada educado", "inculto", propio de "brutos" el uso del masculino (Perú, Cuba, Argentina), en la línea del diccionario académico de 1927 que, como se apuntó, lo consideraba un "barbarismo". También sobresalen los de los argentinos, mexicanos o chilenos que, apoyándose muchas veces en la tradicional disputa (y confusión conceptual) sobre el sexo y el género, no encuentran razones en el sustantivo sartén para considerar erróneo su uso masculino ni femenino: "para mí no debería ser ni el ni la porque, a ver... ¿cómo se determina el sexo de un/a sartén, una mesa, una silla o un auto?" (según una usuaria argentina del WordReference). Por eso resulta tan acertada la reflexión que hace un hablante mexicano cuando indica que sartén tiene género vacilante en el mundo hispano "y no es una cosa sociocultural, ya que hasta la gente más culta dice el sartén, sino dialectal (por región)". Estamos, por tanto, ante un ejemplo magnífico de variación diatópica aceptada y reconocida por los hablantes que habrá que analizar al lado de otros casos similares para cimentar con ellos el gran proyecto de la gramática histórica hispanoamericana.

\section{BIBLIOGRAFÍA}

Alarcos Llorach, Emilio (1994): Gramática de la lengua española, Madrid, Espasa-Calpe/Real Academia Española.

Alvar López, Manuel y Bernard Pottier (1987): Morfología histórica del español, Madrid, Gredos.

Bello, Andrés (1988): Gramática de la lengua castellana destinada al uso de los americanos, con notas de Rufino José Cuervo, ed. de Ramón Trujillo, Madrid, Arco/Libros.

Bosque, Ignacio y Violeta Demonte (eds.) (1999): Gramática descriptiva de la lengua española, Madrid, Espasa-Calpe/Real Academia Española.

Castillo Venegas, M. a de los Ángeles (2013): "El español de Costa Rica: nivel morfosintáctico", en Miguel Ángel Quesada Pacheco (coord.), El español de América Central: nivel morfosintáctico. Madrid/Frankfurt, Iberoamericana/Vervuert, pp. 297-340.

Chavarría Úbeda, Carmen (2013): "El español de Guatemala en el nivel morfosintáctico: análisis geolingüístico y pluridimensional", en Miguel Ángel Quesada Pacheco (coord.), El español de América Central: nivel morfosintáctico, Madrid/Frankfurt, Iberoamericana/Vervuert, pp. 65-140.

CORDE = Real Academia Española: Banco de datos [en línea], Corpus Diacrónico del Español, $<\mathrm{http}: / /$ www.rae.es $>$.

CORDIAM = Academia Mexicana de la Lengua, Corpus Diacrónico y Diatópico del Español de América, <www.cordiam.org>.

${ }^{9}$ En $<$ http://udep.edu.pe/castellanoactual/la-sarten-o-el-sarten/>. 
CORPES XXI = Real Academia Española: Banco de datos [en línea], Corpus del Español del Siglo XXI, <http://www.rae.es>.

$C R E A=$ Real Academia Española: Banco de datos [en línea], Corpus de Referencia del Español Actual, <http://www.rae.es>.

Cuervo, José Rufino (1907): Apuntaciones críticas sobre el lenguaje bogotano, 5. ed., Paris, A\&A Roger y F. Chernoviz Editores.

Dardel, Robert de (1965): Recherches sur le genre roman des substantifs de la troisième déclinaison, Genève, Droz.

DCECH = Juan Corominas y José Antonio Pascual (1980-1991): Diccionario crítico etimológico castellano e hispánico, Madrid, Gredos.

$D G L A=$ Xosé Ll. García Arias (2002-2004): Diccionario General de la Lengua Asturiana, versión en línea, Oviedo, Editorial Prensa Asturiana, $<\mathrm{https} / /$ mas.lne.es/diccionario/>.

Díaz Cano, Tania E. y Christian López (2013): "Morfosintaxis del español de Nicaragua", en Miguel Ángel Quesada Pacheco (coord.), El español de América Central: nivel morfosintáctico. Madrid/Frankfurt, Iberoamericana-Vervuert, pp. 225-296.

DLE = Real Academia Española (2014): Diccionario de la Lengua Española, 23. ${ }^{\mathrm{a}}$ ed., $<\mathrm{http} . / /$ www.rae.es>.

DPD = Real Academia Española (2005-): Diccionario Panhispánico de Dudas, <http.// www.rae.es>.

Echaide Itarte, Ana M. a (1969): "El género de los sustantivos en español. Evolución y estructura", Ibero-Romania, 1, pp. 84-124.

Ernout, Alfred (1953): Morphologie historique du Latin, Paris, Klincksieck.

Gómez Torrego, Leonardo (1998): Gramática didáctica del español, Madrid, SM.

Gómez Torrego, Leonardo (2005): Nuevo manual de español correcto, Madrid, Arco/Libros.

Henríquez Ureña, Pedro (1921): "Observaciones sobre el español de América", Revista de Filología Española, VIII, pp. 357-390.

Hernández Torres, Ramón A. (2013): "El español de Honduras: nivel morfosintáctico", en Miguel Ángel Quesada Pacheco (coord.), El español de América Central: nivel morfosintáctico. Madrid/Frankfurt, Iberoamericana/Vervuert, pp. 191-224.

Lipski, John M. (1996): El español de América, Madrid, Cátedra.

$N G L E$ = Real Academia Española y Asociación de Academias de la Lengua Española (20092011): Nueva gramática de la lengua española, Madrid, Espasa.

Nieto Jiménez, Lidio y Manuel Alvar Ezquerra (2007): Nuevo Tesoro Lexicográfico del español (s. XVI-1726), Madrid, Arco/Libros.

NTLLE = Real Academia Española: Nuevo Tesoro Lexicográfico del Español, <http:// buscon.rae.es/ntlle/SrvltGUISalirNtlle>.

PRESEEA = Corpus del Proyecto para el estudio sociolingüístico del español de España y de América (2014-), Alcalá de Henares, Universidad de Alcalá, <http://preseea.linguas.net>.

Quesada Pacheco, Miguel Ángel (2013): El español de América Central: nivel morfosintáctico, Madrid/Frankfurt, Iberoamericana/Vervuert.

Quesada Pacheco, Miguel Ángel y Erick Rivera Orellana (2013): "Morfosintaxis del español de El Salvador", en Miguel Ángel Quesada Pacheco (coord.), El español de América Central: nivel morfosintáctico, Madrid/Frankfurt, Iberoamericana/Vervuert, pp. 141-189.

Quesada Pacheco, Miguel Ángel y Tarahy S. Tinoco Rodríguez (2013): “Aspectos morfosintácticos del español de Panamá”, en Miguel Ángel Quesada Pacheco (coord.), El español de América Central: nivel morfosintáctico, Madrid/Frankfurt, Iberoamericana/Vervuert, pp. 341-378.

Real Academia Española y Asociación de Academias de la Lengua Española (2010): Diccionario de Americanismos, Madrid, Santillana.

Rosenblat, Ángel (1947): "Género de los sustantivos en - $e$ y en consonante", en Marcelino Menéndez y Pelayo, Estudios dedicados a Menéndez Pidal, Madrid, CSIC, III, pp. 161-163. 
Rosenblat, Ángel (1948): Notas de morfología dialectal, Buenos Aires, Biblioteca de Dialectología Hispanoamericana.

Rosenblat, Ángel (1949): "Vacilaciones y cambios de género motivados por el artículo", Boletín del Instituto Caro y Cuervo, V, pp. 21-32.

Vila Pujol, M. ${ }^{a}$ Rosa (1992): "Cuestiones de morfosintaxis histórica del género", en Manuel Ariza Viguera (coord.), Actas del II Congreso Internacional de Historia de la Lengua Española, Madrid, Pabellón de España, I, pp. 897-904.

Fecha de recepción: 26 de octubre de 2017

Fecha de aceptación: 5 de diciembre de 2017 